\title{
If it bleeds, it leads: the pathos derby
}

\section{S Shatenstein}

\section{Is obesity supplanting smoking as public health enemy number 1?}

n a major recent review of the causes of death in the USA, ${ }^{1}$ Mokdad and colleagues found, unsurprisingly, that "smoking remains the leading cause of mortality". The authors also concluded, notably, that "poor diet and physical inactivity may soon overtake tobacco as the leading cause of death." The reaction to this news was swift, broad, curious, and instructive.

From around the globe, headlines screamed out variations on the theme: "Fat gains on tobacco as top death factor" (CNN $)^{2}$; "Combating Killers: Fat, Tobacco" (CBS News) ${ }^{3}$; "Fat of the land is killing more Americans than cigarettes" (The Times, London) ${ }^{4}$; "Americans Eating Themselves to Death" (The Scotsman); " US government moves to reduce rampant obesity" (Taipei Times) ${ }^{6}$; "Obésité : le mal du siècle" (Le Figaro, Paris). ${ }^{7}$

Clearly, Mokdad's study in JAMA sounded an alarm, but why, and what precisely was the message? Most newspaper reports, derived from Associated Press (AP) and other wire stories, merely reflected the tone set by a JAMA news release. ${ }^{8}$ News articles routinely explained that "poor diet and physical inactivity caused 400,000 deaths in 2000, a 33-percent jump over 1990" while tobacco related deaths "climbed by less than 9 percent", meaning that "obesity will surpass tobacco if current trends continue".

\section{DISTORTION}

Those numbers are correct, but their front page news spin creates a certain distortion. In fact, that 33\% rise means that "gluttony and sloth" accounted for $16.6 \%$ of all US deaths in $2000(400000$ out of 2.4 million) versus $14 \%$ in 1990 (300 000 out of 2.1 million), while smoking attributable mortality dropped just slightly from 19\% (400 000 out of 2.1 million) to $18.1 \%$ (435 000 out of 2.4 million) over the course of the decade. Out of those fairly subtle, predictable changes (numbers also modulated in the 2000 results by use of a different methodology for calculating obesity related deaths ${ }^{9}$ ), comes a relative sense of urgency about obesity and complacency about smoking.
One editorial cartoonist summed it up perfectly with a Marlboro style pack of "smokes" featuring Big Tobacco's new labels: "Warning: Sure smoking causes cancer but millions of Americans will die from being inactive tubs of goo anyway so what have you got to lose? ${ }^{10 \prime \prime}$ (See next page for related cartoons.)

The Campaign for Tobacco-Free Kids (CTFK) felt compelled to issue a press release, ${ }^{11}$ cutting through distorting layers of media flab to pointedly note a key conclusion from Mokdad and colleagues: "The most disappointing finding may be the slow progress in reducing tobacco-related mortality."

The JAMA authors ultimately state that their findings "argue persuasively that the need to establish a more preventive orientation in the US health care and public health systems has become more urgent". Not smoking prevention or obesity prevention, but simply an overall "more preventive orientation"

It is a sad commentary when tobacco control advocates have to cry "don't forget about us" and jostle to retain a firm grip on the crown of misery. However, given chronic and criminal underfunding for all preventive health measures, CTFK may have rightly been troubled by messages from CDC (Centers for Disease Control \& Prevention) director Dr Julie Gerberding and HHS (Health and Human Services) Secretary Tommy G. Thompson.

Gerberding, one of the JAMA study authors, said: "At CDC, we're going to do everything we can to prevent [obesity overtaking smoking]. Obesity has got to be job No. 1 for us in terms of chronic diseases." The widely repeated press conference sound bite from Thompson was "We're just too darn fat, ladies and gentlemen, and we're going to do something about it". He wasn't heard saying anything about how "darn much" Americans smoke.

\section{OVERLAPPING ISSUES}

The overlapping issues of relative risk, public risk perception, and funding of prevention versus treatment are hardly new, nor are they limited to the USA. A recent UK King's Fund paper ${ }^{12}$ surveyed news coverage of various health risks

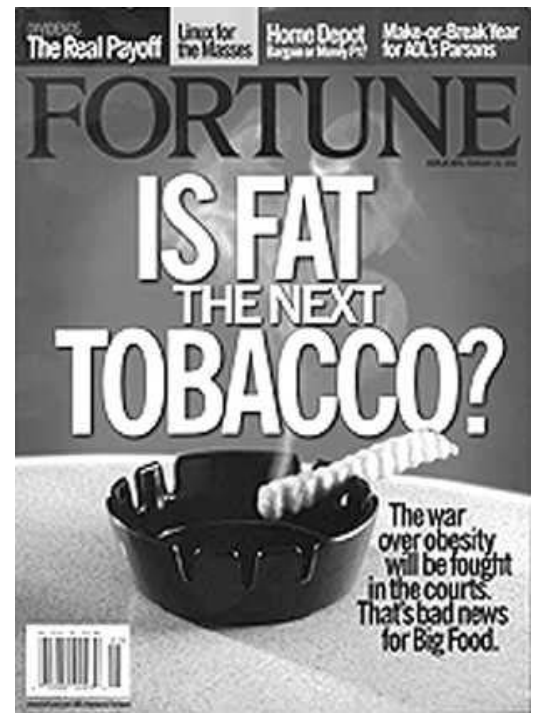

and found it "infinitely more difficult [for public health specialists] to cultivate media interest in serious, proven health risks, such as smoking, alcohol and obesity, than in, for example, 'crises' in the NHS [National Health Service]" or "unusual hazards" like SARS (sudden acute respiratory syndrome).

The authors actually found that it took the death of 0.33 people from variant Creutzfeldt-Jakob disease (vCJD) to merit a news report on the $\mathrm{BBC}$ (this is, three stories for every fatality) against 8571 smoking deaths to warrant a single story, ${ }^{13}$ an astonishing ratio of almost 26000-to-one. The newspapers under review fared somewhat better, but the ratio was still nearly 3000-to-one in favour of VCJD.

Roger Harrabin, who wrote the King's Fund paper while on sabbatical from the BBC, cautions: “we shouldn't forget that policy makers are often influenced by what they see in the media. The public may also alter their behaviour in ways that affect their health because of information and advice they get from the media." Harrabin also allows that health professionals "are pretty hopeless" at using the media to get across the message. ${ }^{14}$ A special $B M J$ issue that explored many of the difficulties and failures inherent in physicians' communication of risk reached equally sobering conclusions. ${ }^{15}$

The shouting for attention from tobacco control advocates and the failings of health professionals are not hard to understand. Just two days after the release of the JAMA report, multiple terrorist attacks at Madrid train stations $^{16}$ left over 200 dead and close to 1500 injured. It would be unconscionable to argue that since smoking kills 


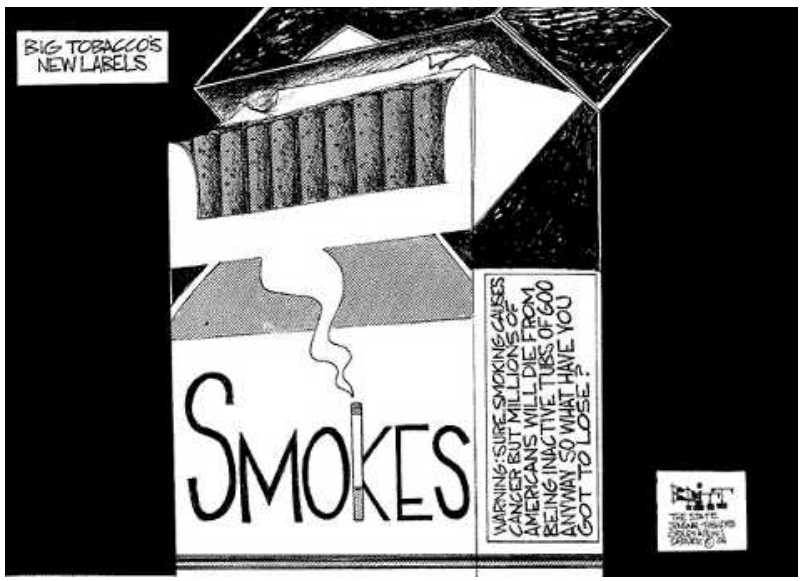

(c) Chris Britt: (Springfield, Illinois) State Journal-Register 2004

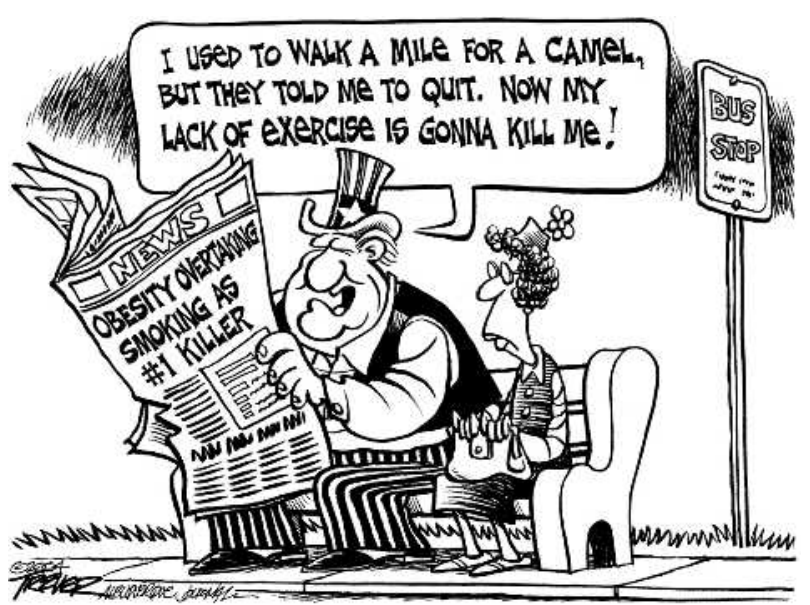

(C) John Trever: The Albuquerque (New Mexico) Journal 2004

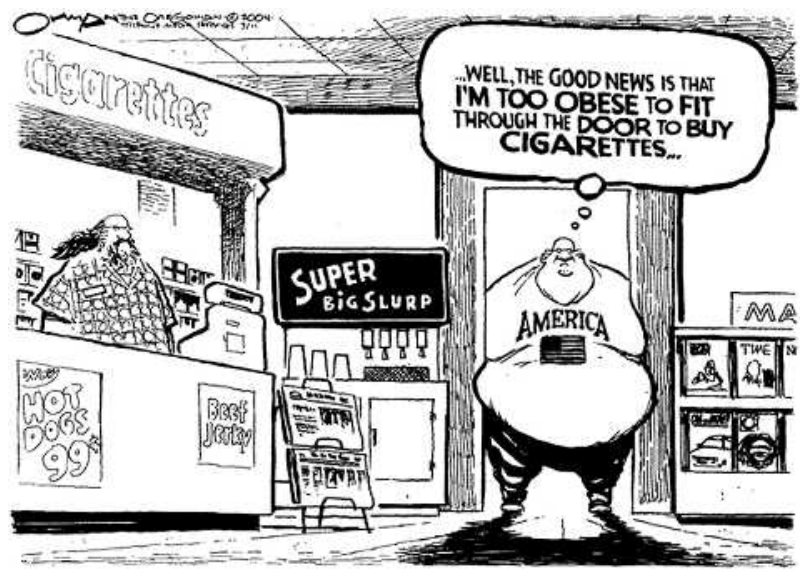

๑) Jack Ohman: The Portland Oregonian 2004

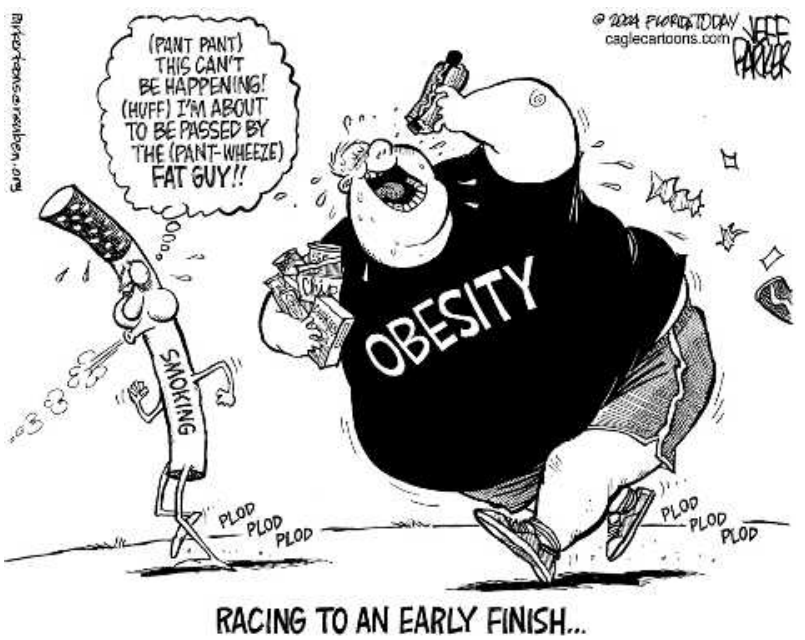

(C) Jeff Parker: Florida Today 2004 some 46000 Spaniards a year, ${ }^{17}$ or 126 a day, the bombings were "no worse" than a couple of days' toll from tobacco. The same logic, applied to the World Trade Center bombings, would have made September 11 no worse than a few days' dying from tobacco related disease, and the message would have been equally abhorrent. ${ }^{18}$

If it bleeds, it leads, according to the hoary news maxim. Given that, the seemingly bloodless battles against the ravages of tobacco and obesity are being fought on much the same ground. While anti-obesity advocates don't have the central villain of Big Tobacco to fight, nor a singular, central product that "kills when used exactly as directed by the manufacturer", fat has been the "next tobacco"1920 for some time now.

John Banzhaf, who founded ASH (Action on Smoking and Health) in the USA and was instrumental in applying the Fairness Doctrine to get tobacco ads removed from the airwaves more than 30 years ago, ${ }^{21}$ has adapted arguments he used in fighting Big Tobacco to now combat the fast food industry.

\section{COMBATTING "BIG FAST FOOD"}

The "Big Fast Food" lobby is clearly feeling pressure from many quarters. In perhaps coincidental timing, the US House of Representatives passed the Personal Responsibility in Food Consumption Act, ${ }^{22}$ the "Cheeseburger Bill', just a day after release of the Mokdad JAMA study. The Bill, which must also be passed by the Senate to become law, shields fast food firms from obesity related lawsuits ${ }^{23}$ and has already been denounced as a cave-in to the fast food industry. ${ }^{24}$

In a related development, McDonald's eliminated its notorious, mega-caloric "Super Size" promotions, ${ }^{25}$ a move many felt was spurred by a fear of lawsuits and, more particularly, the release of the film "Super Size Me". In this documentary, director and star Morgan Spurlock becomes seriously ill after forcing himself to eat only McDonald's fast food for a month. ${ }^{26}$

Clearly, public health advocates cannot help but use overlapping tactics to vie for attention, funding, and policy change in a world where the greater psychic torment inherent in threats of terror and acute illness will continue to dominate public discourse.

The same day the JAMA review was published, Canadian and US researchers presented promising findings on rimonabant, ${ }^{27}$ a selective cannabinoid type 1 receptor blocker that may double cessation rates and also speed up weight loss, helping kick both "flabby and smoky butts". ${ }^{28}$

No one drug is even remotely likely to be the answer that will radically reduce the millions of deaths from smoking and obesity every year. Still, with increasing competition for limited resources, rimonabant may yet be called upon to stand with higher tobacco taxes, smoke-free public places, and cessation services, and alongside more exercise and less dietary fat in the ongoing battle against public health's twin perils

Tobacco Control 2004; 13:97-99.

doi: $10.1136 /$ tc. 2004.008276

Correspondence to: Stan Shatenstein, 5492-B Trans Island, Montreal, Quebec H3W 3A8; shatensteins@sympatico.ca 


\section{REFERENCES}

1 Mokdad $\mathbf{A H}$, et al. Actual causes of death in the United States, 2000. JAMA 2004:291:1238-45, http://jama.ama-assn.org/cgi/content/ abstract/291/10/1238

2 Anon. Fat gains on tobacco as top death factor. AP(Associated Press)/CNN, March 9, 2004. http://edition.cnn.com/2004/HEALTH/ diet.fitness/03/09/obesity.ap/index.html.

3 Anon. Combating Killers: Fat, Tobacco. AP/CBS News. March 9, 2004. http:// www.cbsnews.com/stories/2004/03/09/ health/main604980.shtml

4 Wapshott N. Fat of the land is killing more Americans than cigarettes. The Times, London, March 11, 2004. http://www.timesonline.co.uk/ article/0,8122-1034026,00.html

5 Anon. Americans Eating Themselves to Death. PA (Press Association) News/The Scotsman, March 10, 2004. http://news.scotsman.com/ latest. $\mathrm{cfm}$ ? id = 2630731

6 Anon. US government moves to reduce rampant obesity. AP/Taipei Times. March 11, 2004. http://www.taipeitimes.com/News/world/ archives/2004/03/11/2003102015.

7 Perez, M. Obésité : le mal du siècle. Le Figaro, March 11, 2004. http://www.lefigaro.fr/ sciences/2004031 1.FIG0150.html.

8 Anon. Poor diet and physical inactivity may soon overtake tobacco as leading cause of death in U.S. JAMA news release/EurekAlert. March 9, 2004. http://www.eurekalert.org/pub_releases/ 2004-03/jaaj-pda030404.php

9 McGinnis JM, Foege WH. The immediate vs the important [editorial]. JAMA 2004;291:1263-4, http://jama.ama-assn.org/cgi/content/full/ $291 / 10 / 1263$

10 Britt C. Editorial cartoon. State Journal-Register, Springfield, Illinois. March 12, 2004. http:// cagle.slate.msn.com/working/040312/britt.gif

11 Myers ML. New JAMA/CDC study finds tobacco use remains no. 1 cause of preventable death but U.S. is not doing enough to fight it. Campaign for Tobacco-Free Kids. March 9, 2004. http://
www.tobaccofreekids.org/Script/ DisplayPressRelease.php3?Display $=733$

12 Harrabin $\mathbf{R}$, et al. Health in the news: risk reporting and media influence. King's Fund. 2003. http://www.kingsfund.org.uk/pdf/ healthinthenewssummary.pdf

13 Jackson T. News skews health priorities, study claims. BMJ 2003:327:688, http:// bmi.bmijournals.com/cgi/content/full/327/ 7416/688-a.

14 Ferriman A. Public health doctors "hopeless" at using media. BMJ 2003;327:1056. http:// bmi.bmijournals.com/cgi/content/full/327/ 7422/1056-a.

15 Smith R. Communicating risk: the main work of doctors. BMJ 2003;327:7417. http:// bmj.bmijournals.com/cgi/content/full/327/ 7417/0-f.

16 Edición especial. Masacre en Madrid. ABC, March 11, 2004. http://n labc10.abc.es/abc/ laterales/otro_contenido/documentos_pdf/ especial 1 1032004.pdf.

17 Peto R, Lopez AD, et al. Mortality from smoking in developed countries 1950-2000. Oxford University Press. 2nd ed: data updated 15 July 2003. http://www.ctsu.ox.ac.uk/ tobacco/ MN_AP_4280.pdf.

18 Chapman S, Shatenstein S. The banality of tobacco deaths. Tobacco Control 2002;1 1:1-2 http://tc.bmijournals.com/cgi/content/full/11/ $1 / 1$.

19 Parloff R. Is fat the next tobacco? Fortune. 27 January 2003. [Cover Date February 3, 2003] http://www.fortune.com/fortune/articles/ $0,15114,409670,00 . \mathrm{html}$

20 Mitchell A. Fat: the next tobacco. The Globe and Mail, Toronto. July 5, 2003. http:// www.globeandmail.com/servlet/ArticleNews/ TPStory/LAC/20030705/FCWIDE/TPHealth/.

21 Anon. Federal Communications Commission and Cigarettes. Tobacco Institute, September 1974. Bates 00135409-00135417. Accessed via TobaccoDocumentsOnline, March 16, 2004. http://tobaccodocuments.org/ness/ 7613.html.
22 US House of Representatives. H.R.339. Obesity Lawsuits bill. Personal Responsibility in Food Consumption Act. OFFICIAL TITLE AS AMENDED BY HOUSE: To prevent legislative and regulatory functions from being usurped by civil liability actions brought or continued against food manufacturers, marketers, distributors, advertisers, sellers, and trade associations for claims of injury relating to a person's weight gain obesity, or any health condition associated with weight gain or obesity. Passed by the Yeas and Nays: 276-139, March 10, 2004. http:// www.congress.gov/cgi-bin/bdquery/ z?d108:HR00339:@@@X

23 Goldenberg S. US shields fast-food firms from obesity cases. The Guardian, March 12, 2004. http://www.guardian.co.uk/international/story/ 0,3604,1 167696,00.html.

24 Anon. Mixed messages on obesity. Boston Globe, March 15, 2004. http://www.boston.com/ news/globe/editorial_opinion/editorials/ articles/2004/03/15/mixed_messages_on_ obesity/.

25 McSupersizes to be phased out. CNN.com March 3, 2004. http://edition.cnn.com/2004/ US/03/02/mcdonalds.supersize.ap/index.htm

26 Friedman R. Fast Food Backlash Prompted by New Movie? Fox News, March 11, 2004. http://www.foxnews.com/story/ $0,2933,113885,00 . \mathrm{html} \# 2$

27 Anthenelli RM, Pierre Despres J-P. Effects of rimonabant in the reduction of major cardiovascular risk factors. results from the STRATUS-US trial (smoking cessation in smokers motivated to quit and the RIO-LIPIDS trial (weight reducing and metabolic effects in overweight/ obese patients with dyslipidemia). Presented at the American College of Cardiology Annual Scientific Session, New Orleans. March 9, 2004 http://www.acc04online.org/daily/news/ newssummary. asp? sid $=1$ \&stid $=14$ \&newsld $=$ 2004-03-09.

28 Rosinski J. New 'wonder drug' helps kick both flabby and smoky butts. Boston Herald. March 10, 2004. http://theedge.bostonherald.com/ healthNews/view.bg?articleid $=142$.

\section{The lighter side}

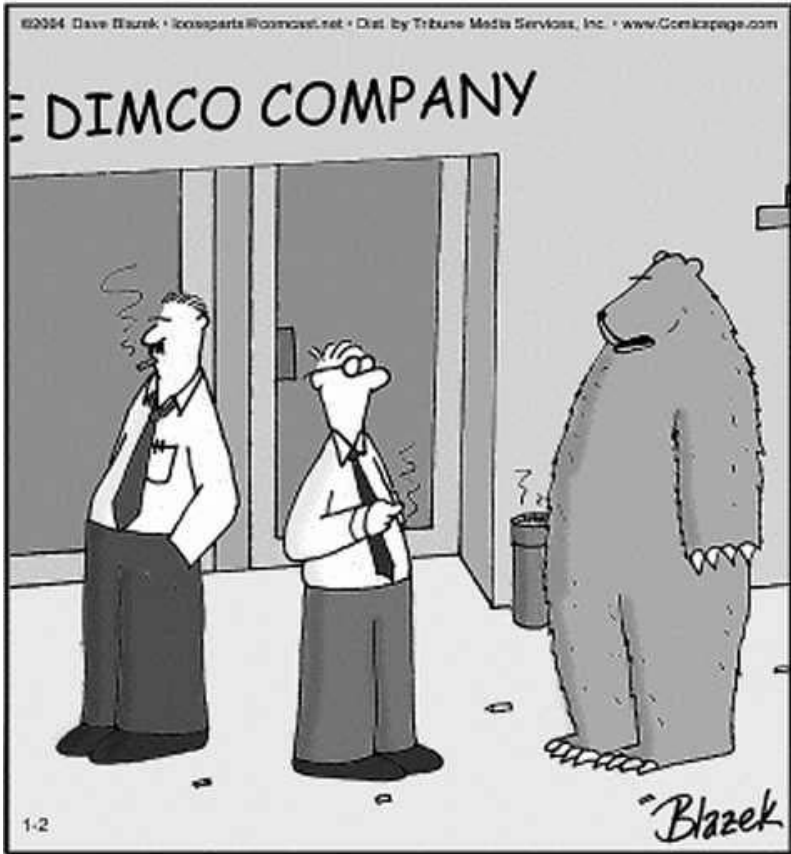

"No, I don't smoke. I'm out here because the building just went maul-free." 